\title{
Utilization of Mangrove Wood Products around Mida Creek (Kenya) Amongst Subsistence and Commercial USERS $^{1}$
}

\author{
F. Dahdouh-Guebas, C. Mathenge, J. G. Kairo, and N. Koedam
}

\begin{abstract}
Dahdouh-Guebas, F. (Laboratory of General Botany and Nature Management, Mangrove Management Group, Vrije Universiteit Brussel, Pleinlaan 2, B-1050 Brussel, Belgium), C. Mathenge (Laboratory of General Botany and Nature Management, Mangrove Management Group, Vrije Universiteit Brussel, Pleinlaan 2, B-1050 Brussel, Belgium), J. G. Kairo (Kenya Marine and Fisheries Research Institute, PO Box 81651, Mombasa, Kenya and Laboratory of General Botany and Nature Management, Mangrove Management Group, Vrije Universiteit Brussel, Pleinlaan 2, B-1050 Brussel, Belgium), and N. Koedam (Laboratory of General Botany and Nature Management, Mangrove Management Group, Vrije Universiteit Brussel, Pleinlaan 2, B-1050 Brussel, Belgium). Utilization of Mangrove Wood Products around Mida Creek (Kenya) Amongst Subsistence And Commercial Users. Economic Botany 54(4):513 527, 2000. Mida Creek (Kenya) comprises mangrove forests and other marine resources that are of economic, ecological, and environmental importance to the local village communities. In total 116 households (100 of which could be used for numerical analysis), which are estimated to correspond to a coverage of ca. $30 \%$ of the total Mida Creek population, were interviewed to assess the human reliance on mangrove resources in Mida Creek. The survey indicates that mangroves are a major resource of wood for house construction, fuel wood, charcoal, and boat building. Minor uses of mangrove products include pharmaceutical and medicinal applications, tanning material, and furniture making. Rhizophora mucronata, Ceriops tagal, and Bruguiera gymnorrhiza are the major resources for house construction and fuel wood, while Sonneratia alba and Xylocarpus granatum were reported to be useful for boat building and medicinal uses respectively. The survey further describes harvesting activities and house construction, and reveals species preferences within this one particular use. As a result of depletion of the supply and the banning of mangrove harvesting, the local people are turning to other wood materials and to poaching. In our view, local utilization patterns rather than global usefulness data are required to establish a conservation policy of both mangroves and users' subsistence requirements.
\end{abstract}

Utilización de Productos de la Madera del Mangle Alrededor de Mida Cala (Kenya) entre Subsistencia y Usuarios Comerciales. La ensenada de Mida (Kenya) posee bosques de manglar y otros recursos marinos de importancia económica, ecológica y ambiental para las comunidades de los pueblos. En total 116 hogares (100 de los cuales podrían ser usados para análisis numéricos) corresponden a una cobertura total del $24 \%$ de la totalidad de la población de ensenada de Mida. El sondeo indica que los manglares son la mayor fuente de madera para la construcción de casas y botes, combustible y carbón de madera. Usos menores de los productos de manglar incluyen aplicaciones farmacéuticas y medicinales, material de teñido y muebles. Rhizophora mucronata, Ceriops tagal y Brugeuiera gymnorrhiza son las principales fuentes para combustible y construcción de casas, mientras que Sonneratia alba y Xylocarpus granatum fueron reportados como aptos para la construcción de botes y usos medicinales respectivamente. El sondeo describe adicionalmente actividades de consecha y construcción de casas revelando preferencias de especies para este caso en particular. Como resultado de la destrucción del recurso y la prohibición de la cosecha de mangle, los pobladores se han inclinado por el uso de otras maderas y a la pesca furtiva. Consideramos que se requieren patrones de utilización local más que datos globales para establecer una política de conservación de manglares y requerimientos para la subsistencia de los usuarios.

Key Words: mangrove; ethnobotany; wood; survey analysis; Kenya.

${ }^{1}$ Received 24 July 1999; accepted 21 March 2000.

Economic Botany 54(4) pp. 513-527. 2000

(C) 2000 by The New York Botanical Garden Press, Bronx, NY 10458-5126 U.S.A. 
All over the world the mangrove ecosystem is threatened with destruction through various forms of human pressure (e.g., Farnsworth and Ellison 1997). The observed decline in Kenya is mainly a result of mangrove harvest exports as building material and fuel wood to Somalia, Saudi Arabia, and other Middle East countries (Rawlins 1957). Mangroves are well developed in many areas along the Kenyan coastline, particularly in creeks, bays, and estuaries. Estimates of total area of mangrove forest vary according to different sources. The Kenya Forestry Department lists $644 \mathrm{~km}^{2}$, the World Mangrove Atlas $961 \mathrm{~km}^{2}$ (Spalding, Blasco, and Field 1997), but the more rigorous studies made by Doute, Ochanda, and Epp (1981) indicate that there are $530 \mathrm{~km}^{2}$ of mangroves along the Kenyan coast, the bulk of which are in Lamu $\left(335 \mathrm{~km}^{2}\right)$ with substantially smaller areas in Kwale $\left(88 \mathrm{~km}^{2}\right)$, Kilifi $\left(66 \mathrm{~km}^{2}\right)$ and Mombasa districts $\left(20 \mathrm{~km}^{2}\right)$. All nine typical East-African mangrove species occur along the Kenyan coast, i.e., Avicennia marina (Forsk.) Vierh., Bruguiera gymnorrhiza (L.) Lam., Ceriops tagal (Perr.) C.B. Robinson, Heritiera littoralis Dryand., Lumnitzera racemosa Willd., Pemphis acidula Forst., Rhizophora mucronata Lam., Sonneratia alba Sm., Xylocarpus granatum Koen, and $X$. moluccensis (Lamk.) Roem. (nomenclature according to Tomlinson 1986). However, on a local level not necessarily all of these are present (DahdouhGuebas et al. subm.).

The people of the Kenyan coast (Swahili community) are united by their common language (Kiswahili, but in the area of Mida Creek Giriama is common as well), common culture and religion (Islam), and common home, the coastal zone (Salim 1985). Most of these people have strong economic ties with the coastal ecosystems with which they interfere, as fishermen, as mangrove cutters, as coral collectors, and so forth.

The main reason for this study arose from some policy developments concerning environmental resources in Kenya in 1996, involving a proposal to lift a ban on mangrove export (initially in place in 1978, lifted in 1981 and again installed in 1982). Authorization for the exploitation and clearing of mangroves for any purpose has to be obtained from the Kenya Forestry Department at the Ministry of Environment and Natural Resources. In addition to controlling operations, all vehicles transporting mangrove poles must have a transit permit and timber statement. The local communities were affected in many ways by these measures as they have lived within the mangrove forests for several generations or visited them to make use of their resources. Restricting access through changes in property rights has been shown elsewhere to increase poverty (Reddy and Chakravarty 1999). The issues of indigenous resource rights and environmental conservation have been reported to be complementary as well as contradictory, as highlighted by Aagesen (1998).

The objectives of this study were: (a) to provide data on the uses of mangroves by local communities within and around Mida Creek; (b) to assess the most significant use of the mangroves for these communities; (c) to investigate the local residents' perception of the current status of the mangrove forest; and (d) to examine the factors influencing frequency of harvesting activities, preferred harvesting areas, preferred species and actual organization of the harvesting activities. The combination of this information may give a clue to establish the community's dependence on the mangrove resource.

\section{Description of the Sites Studied}

Mida Creek $\left(03^{\circ} 21^{\prime} \mathrm{S}, 39^{\circ} 59^{\prime} \mathrm{E}\right)$ is located in Malindi district, $88 \mathrm{~km}$ north of Mombasa and approximately $25 \mathrm{~km}$ south of Malindi town (Fig. 1). The creek lies in a planigraphic area of $31.6 \mathrm{~km}^{2}$ (Brakel, 1979).

In recognition of its scenery both above and below the water level Watamu Marine National Reserve in Mida Creek was declared a protected area, one out of the three protected areas with mangroves in Kenya (Spalding, Blasco, and Field 1997). It was established as a reserve in 1968, and gazetted under the Wildlife Conservation Management Act in 1976. In 1979, Watamu Marine National Reserve was designated the status of a Biosphere Reserve together with the adjoining coast (Kennedy 1988). Mida Creek has a number of distinct habitats comprising mangrove forest, sand flats, rock outcrops, seagrass beds, coral growths, and deep water. Unlike most of the coastal areas in Kenya, Mida Creek lacks overland freshwater input (cf. Fig. 1a).

Administratively the Mida Creek area was divided into two sublocations: Gede and Matsangoni. For the purpose of this study we considered the area bordered by the Mombasa-Malindi 


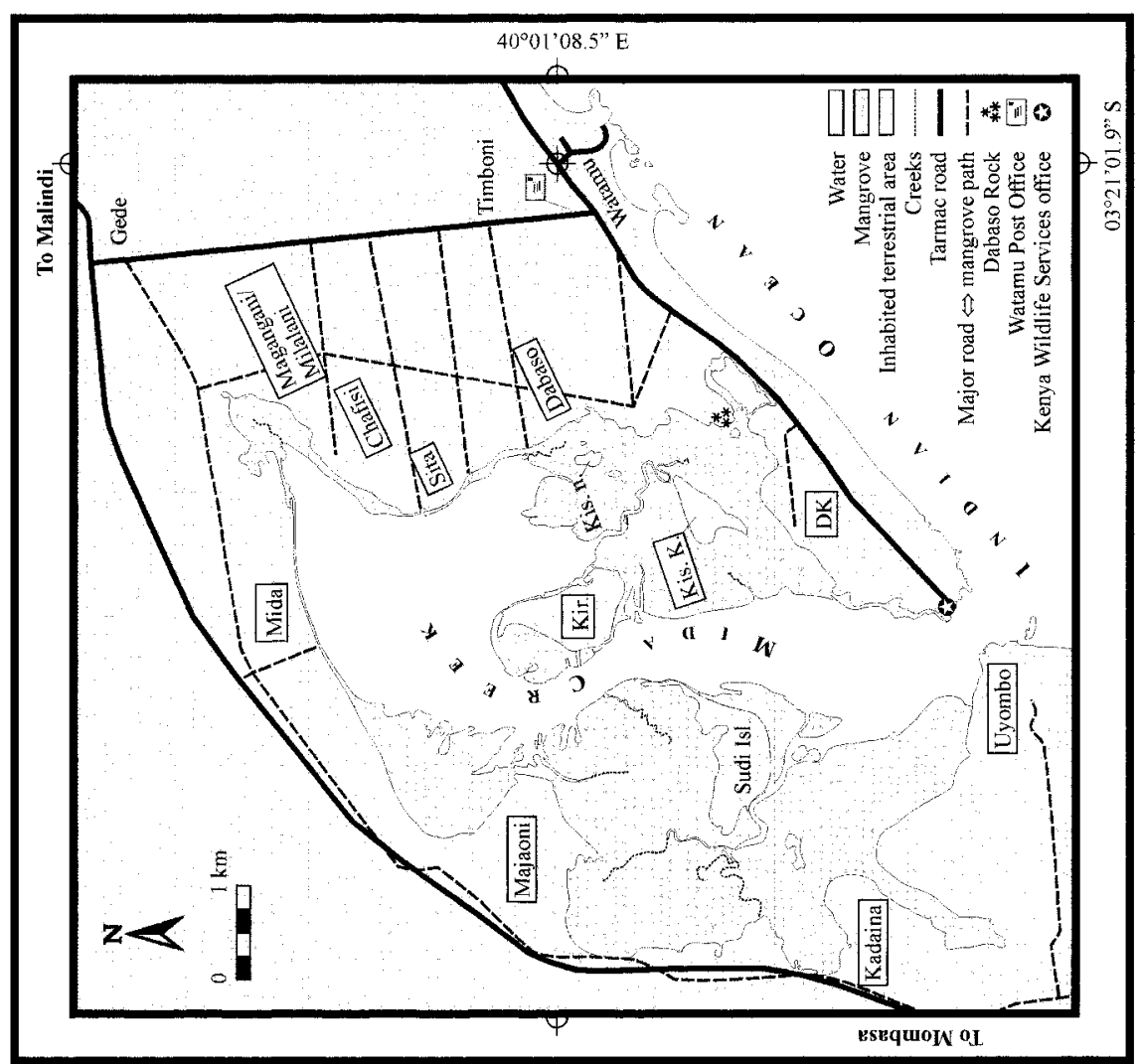

苛

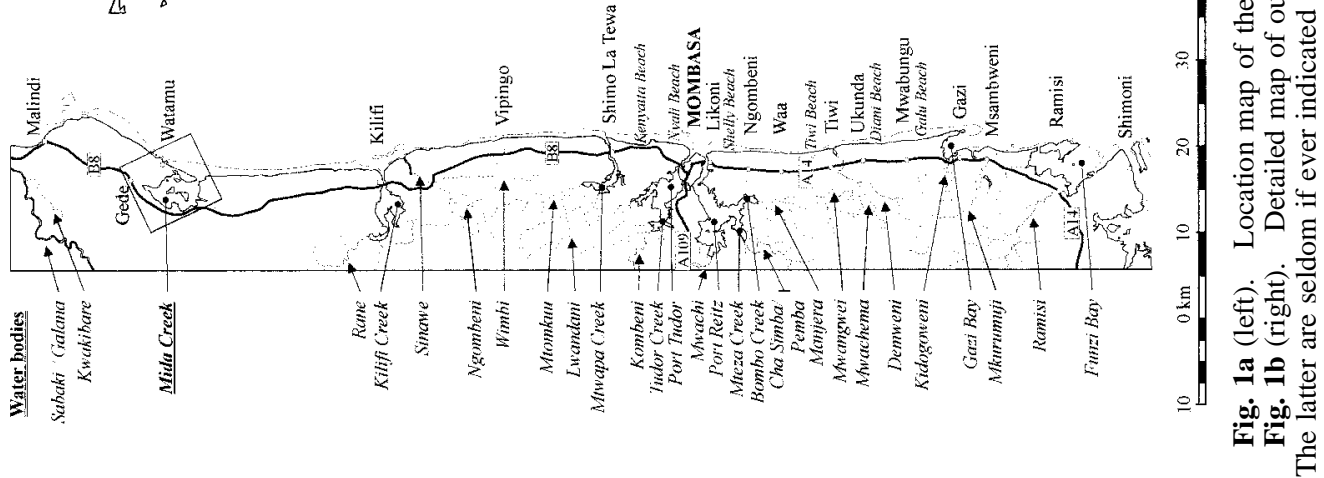


main road east, excluding the northwestward regions further away from the creek in the Gede sublocation. According to official records, the 1991 census for Kenya revealed the population of Mida Creek as approximately 23000 , of whom $60 \%$ are below the age of 16 . An estimated $20 \%$ of this population live in the trade centers in Timboni and Gede and the Watamu tourist village, which are two to three $\mathrm{km}$ distant from the mangroves. Timboni is a small trading center that deals with mainly farm produce from Mombasa and up-country. It is also an important trading area for building materials like mangrove poles, bricks, gravel and cement. Gede on the other hand is an important historical village with $16^{\text {th }}$ century ruins. In addition, it is a trade center for agricultural produce, and at present also the home of the Kipepeo Butterfly Project, that cultures the endemic Lepidoptera species of Arabuko Sokoke National Park, the largest block of indigenous coastal terrestrial forest in East Africa (KIFCON 1995). The people of these villages derive their livelihood from trading foodstuffs, building material, curios, and souvenirs to tourists and as government administration. Besides the villages that dot the area around the entire creek, the shore is lined with tourist lodges as well as properties owned by foreign residents (Hirsch and Mauser 1992).

\section{Material And Methods}

Data collection was done by interviews at 116 households around the creek, systematically filling out questionnaires (Appendix 1), and through observation of everyday life in the households visited. One hundred questionnaires were used for numerical analysis (see below). Only one person per household was interviewed to avoid repetition from members of the same household, who could, however, interfere with the interview. Households were approached directly in the field, as topographic or administrative maps showing their distribution were unavailable. In densely populated areas, such as Uyombo and Dongokundu, systematic sampling was done by visiting every second household, whereas in sparsely populated areas all households were visited (e.g., Kisiwani Island and Chafisi). The settlements of Timboni and Gede were not included in the survey for reasons outlined in the introduction. Secondary data were pursued from official government records, but the archival research was restricted by the local authorities because of the highly unstable political situation at the time of data collection in the national election year 1997.

The interviews were conducted in Kiswahili and/or the local Giriama, depending on which of the languages the respondents felt more comfortable with. Often the elderly folk preferred to communicate in Giriama, whereas the middleaged people and the youth felt more comfortable using Kiswahili. A guide, a local resident, facilitated moving around the creek reducing possible hostility, facilitating a comfortable reception and a fluent conversation with the respondents in the visited households. The information gathered was then filled out in questionnaire schedules in English. The questionnaire involved questions that sought to provide general information about the respondents, questions posed to reveal "the way of forest life" of the members of the community, i.e., how they conducted various activities in the forest and what kind of preferences they had, as well as questions aimed at bringing out the respondents' opinions concerning various issues (public opinion polls; Bailey 1987). The questionnaire had a semistructured nature with short multiple-choice questions as well as some open-ended questions, the former of which mainly aimed at narrowing down the answer categories to facilitate and enhance data analysis. The interviews often began by assessing the understanding of the term mangrove to ensure that the respondent and interviewer were talking about the same concept and subject area. As it turned out, the respondents referred to the vegetation whenever they used the Kiswahili or Giriama term corresponding to mangrove (mkoko) rather than to the entire mangrove ecosystem.

In situations where cultural inhibitions limited or prevented the respondents from answering certain questions, visual observation was substituted as a method to acquire the required information. In the other situation observations were important to visually check and complete the respondent's answers. Some of the uses of mangroves were quite easily observable, e.g., making furniture, cooking utensils, fishing traps, canoes, and sailboats and in building houses. This observation technique provided supplementary information to that gathered in the interviews.

The few problems met during the survey related to the sensitivity of certain issues. Given the current policy on mangrove exploitation in 


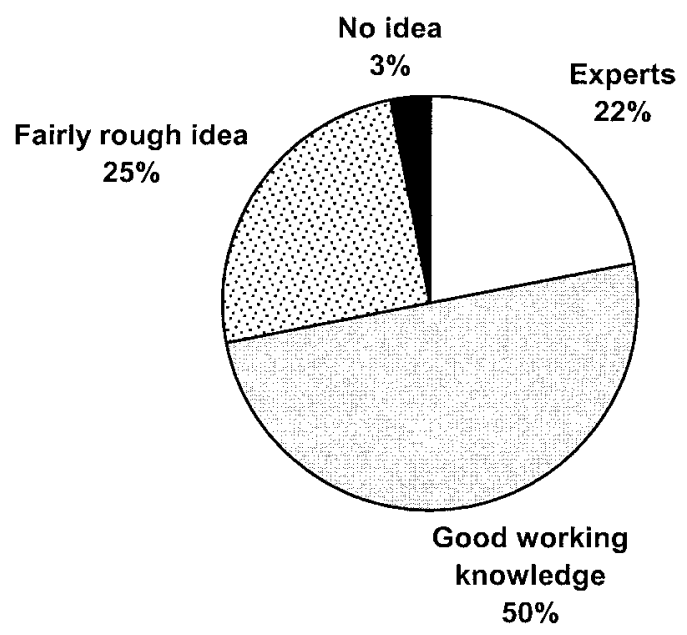

Fig. 2. Levels of knowledge on mangroves amongst the survey respondents.

Kenya, the entire subject has become a sensitive one. Questions dealing with mangrove pole harvesting often result in a lot of suspicion, which made the gathering of information from outsiders rather complicated. Often it took a long conversation to win the confidence of the respondent so that they felt comfortable enough to answer questions. To obtain sensitive demographic data community leaders were approached.

In addition to the individual questionnaires a group interview with the Viriko-Vimoyoni Women's group, which owns a mangrove-harvesting permit, was done.

\section{Results AND Discussion}

A total of 11 settlements can be mapped out distinctly from the study (Fig. 1). These settlements are immediately bordering the creek area, but are seldom, if ever, indicated on (official) maps, notwithstanding they form an important form of identity for the residents. Most residents were native to the area, having lived there for at least three generations. The main human settlements include: Dongokundu, Kisiwani, Dabaso, Sita, Chafisi, Magangani-Milalani, Mida, Majaoni, Kadaina, Uyombo, and Kirepwe (Fig. 1b).

From visual observation it was clear how much the villagers' lifestyle revolves around the mangrove ecosystem, on one hand because they are mainly fisher folk dependent on the functions of mangrove as breeding, spawning, hatching, and nursing grounds for many marine and

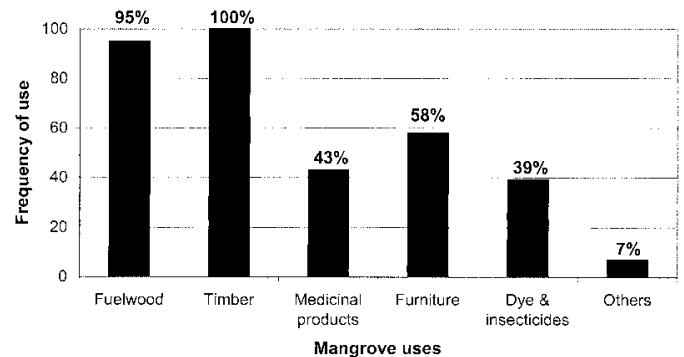

Fig. 3. Different uses of mangroves $(n=100$ respondents).

lagoon animal species, and on the other hand because of the massive use of mangrove trees within their households.

\section{The Household EnTity}

Traditionally, a woman and her children share a house. Each homestead included one house for the man who is the family head, one for each of his wives and her children (the predominant Giriama culture in this area is polygamous), and one house for each of his adult sons, i.e., from the age of 15. Estimating from the fieldwork that a household comprises on average eight houses, each of which counts on average about six persons, the average household has approximately 48 persons. Considering the most recent official statistics of 23000 persons inhabiting the area, and assuming that about $20 \%$ of these live outside the survey area based on the distribution of villages, the 116 households visited are estimated to cover $30 \%$ of the Mida Creek population. However, 16 questionnaires were excluded from the main analysis because of incompleteness, reducing the number of questionnaires suited for further analysis to 100 , and the coverage to $26 \%$ of the population bordering the creek.

\section{MangRove KnOWLedge LeVels}

Different levels of knowledge became evident when interviewing the respondents (Fig. 2). First, experts, as they were referred to by others, who, when interviewed, were able to identify mangrove species using different physiognomic and morphological traits of the plants (e.g., roots, leaves, flowers, and propagules). Second, those who had a good working knowledge on the mangroves and could distinguish different mangrove species through the rooting system alone. These two first groups constituted the ma- 


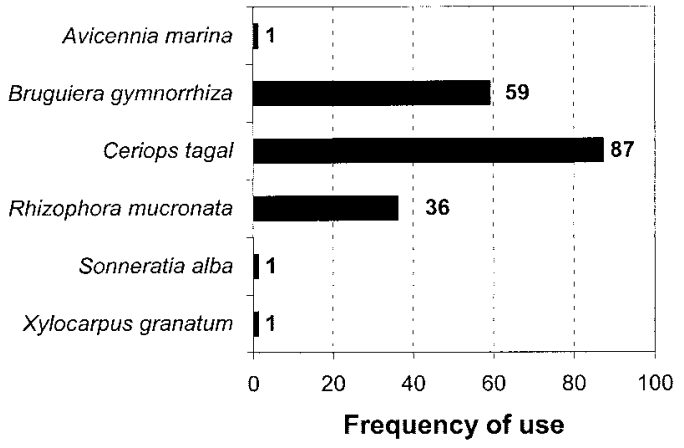

Fig. 4. Mangrove tree species used in house construction ( $\mathrm{n}=100$ respondents). Mangrove wood as a source for construction along the Kenyan coast.

jority of respondents (72\%). Third, those who had a fairly rough idea and could acknowledge the existence of different species, but could almost never go beyond visually naming three species that were present in Mida Creek. Fourth, those with no idea at all, who knew what mangroves were but could not distinguish individual tree characteristics, much less name them.

\section{Local Uses of Mangrove Trees}

Various tree species and tree parts of different sizes were used for different purposes, all of which have been summarized for each species in Table 1 and quantified in Fig. 3. The more direct uses of mangrove trees in making them into furniture of various sorts have been included entirely in Table 1.

Fuel wood comprises firewood and can be turned into charcoal. Firewood is dead logs and branches washed ashore by the tides and gathered by the women, which implies that there is not a preferred species for this use. The making of charcoal, however, as it is for commercial purposes, involves felling trees favoring some species over others because of their heating quality. The whole process of cutting trees for commercial firewood and making charcoal is done by men, except for the actual selling of charcoal, which in the creek area is performed by women.

Medicinal products are mainly made from the bark of mangrove stems, which are crushed and blended with other ingredients or plant extracts before being boiled. Tree stems of different ages yield medicines for different ailments. Rhizophora mucronata roots are often valued for their curative properties for constipation, fertility-related or menstruation disorders. Xylocarpus granatum fruits are used as an ointment to soothe aching muscles and limbs resulting from injury, and mixed with other ingredients (e.g., chalk) they are also used as an ointment to cure skin disorders. An extract from the bark of roots is claimed to drive demons out from possessed persons, and in the case of Rhizophora mucronata roots, to have the power of bringing back lost family members. For both normal and paranormal applications the methods of preparation and proportions of various ingredients are closely guarded family secrets.

Dyes, including tanning compounds, are produced from the bark of Rhizophora mucronata stems, applied to the insides of canoes and boats and valued for their preservative quality. Dyes are also used to seal up the tiny pores in trays woven from reeds and palm leaves, used for storing flour from cereals, and to decorate sleeping mats, baskets, and trays. Among the school children and their teachers, dyes are used in school to produce tie-dye fabrics and clothes but the art is not pursued further for commercial purposes. The insecticide application of mangroves is reported to come mainly from green Avicennia marina logs which are very smoky when burnt, keeping away mosquitoes and other biting night insects. Their slow burning make them also popular with honey collectors or fishermen as they sit out on the beach at night, awaiting the right tide amplitude to set out fishing. However, the fishermen sometimes prefer to set the entire tree ablaze beginning with a hole at the base of the stem. These fishermen's fires are not extinguished so that they find the fire still burning the next nights until the entire tree is burnt out.

The use of mangroves as timber is the most important one (Fig. 3), either for house or boat construction. Simple one-man canoes are carved from heavy Avicennia marina logs. Larger vessels like the traditional dhows are built with ribs from Sonneratia alba logs. The paddles and oars to propel these boats forward are made from pau (see below) of Bruguiera gymnorrhiza, Ceriops tagal, or Rhizophora mucronata, the key features of these poles being their length and straight shape.

Although for some countries, different uses might come out as most important, such as charcoal in Thailand (Aksornkoae, Paphavasit, and 
Wattayakorn 1993), the uses of mangrove wood products generally correspond with those observed earlier by Kokwaro (1985) for the Kenyan coast. The most significant use of mangroves in Mida Creek as a source for house construction, is apparently also the case for other villages along the Kenyan coast (pers. obs.).

Our expectation that local people's opinions would, to a certain extent, vary depending on level of dependence (e.g., fishermen would perceive the most important use as being related to their occupation-fishing, boat construction, making of fishing traps), the mangrove's function as breeding ground for fish is not reported since all respondents unanimously state house building as a prime use (Fig. 3). This is even more surprising when comparing the monthly income for mangrove cutters and fishermen: respectively $2500 \mathrm{KSh}$ and $3500 \mathrm{KSh}$ (Hirsch and Mauser, 1992. The exchange rate at the time of their research was 1 US $\$=32-35 \mathrm{KSh}$, whereas during the course of the present study and until present, it is $1 \mathrm{US} \$=70-74 \mathrm{KSh}$.). Only seven respondents included benefits like preservation of the environment by the mangroves, keeping sea storms and winds at bay by the mangrove tree fringe, and attracting rainfall (Fig. 3). This emphasizes the perception of the mangrove forest as being vegetation rather than the entire ecosystem.

\section{House Construction as the Prime Use}

The largest and most significant use of mangroves is in the form of poles used for house construction. Certain species are preferred over others namely: Ceriops tagal, Rhizophora mucronata, and Bruguiera gymnorrhiza (Fig. 4). These are favored because of their ability to grow long and straight, and each of these species occupies a particular place within the framework of a house. Bruguiera gymnorrhiza is preferred for the rooftops rather than for walls because it produces long yet strong enough poles for the roof. In addition, this species is cited as not lasting very long in the soil as it does not withstand moisture and saline soils. Most resistant to the soil conditions cited above is Rhizophora mucronata and it is preferred for the walls and especially the thicker supportive poles and corner pillars of a house (Fig. 5). Ceriops tagal poles are much thinner and thus used as fito (Table 2; cf. Fig. 5) for creating an interweaving network in the walls and roofs. C. tagal was also used to make other houselike structures like shrines, cooking sheds outside the main house, and animal sheds and pegs (cf. Fig. 6). Classification of mangrove pole diameters and heights was given by Roberts and Ruara (1967) and the uses in a single house qualified and quantified per class according to our data in Table 2. Looking at the construction of a house from the utilization classes point of view we can summarize that the boriti are thick poles that go deep into the ground and that they are the main supports for the walls. At each side of the wall they are crossed by the fito. The fillings of the walls consisted of traditional clay (Fig. 7) or cemented dead coral rock (Fig. 8), whether or not finished with a more modern plaster treatment, depending on financial means. The latter provides a polished look exactly like that of a plastered modern brick house constructed with cement and stone or concrete bricks. The ceiling is made of nguzo and boriti, the former being thicker and heavier than the latter, which could be closely packed or evenly spaced out at one-foot intervals. The roof is composed of pau and mazio, which are long poles meeting at a common apex or at the same level at the top depending on the roof design (Fig. 9). Finally, the vigingi are used to support the roof extension that formed a kind of veranda just outside the main door and is used as a cool or dry sitting area. The most common roof fillings are dried coconut leaves woven into a thatch called makuti (Fig. 9). This material insulates the house adequately from the hot daytime sun. The makuti are placed in an overlapping manner directly onto the grid of mangrove poles and tied with strings made from some indigenous inland creepers, dried coconut leaves split into thin strips, or split roots of Rhizophora mucronata. From our own observations, we estimate that $90 \%$ of the houses in the villages around Mida Creek are of the traditional design, with a bare instead of a cement floor. The average house has an L-shape, consisting of three rooms with one main entrance into the house, and a perimeter of about $27 \mathrm{~m}$.

According to the respondents, once constructed a house can last from one to over 30 years with an estimated average of eight years, depending greatly on the quality of poles and fillings used in the framework and especially whether or not the house has a cement floor and plastered walls. Also, environmental conditions such as soil drainage levels obviously are a fac- 

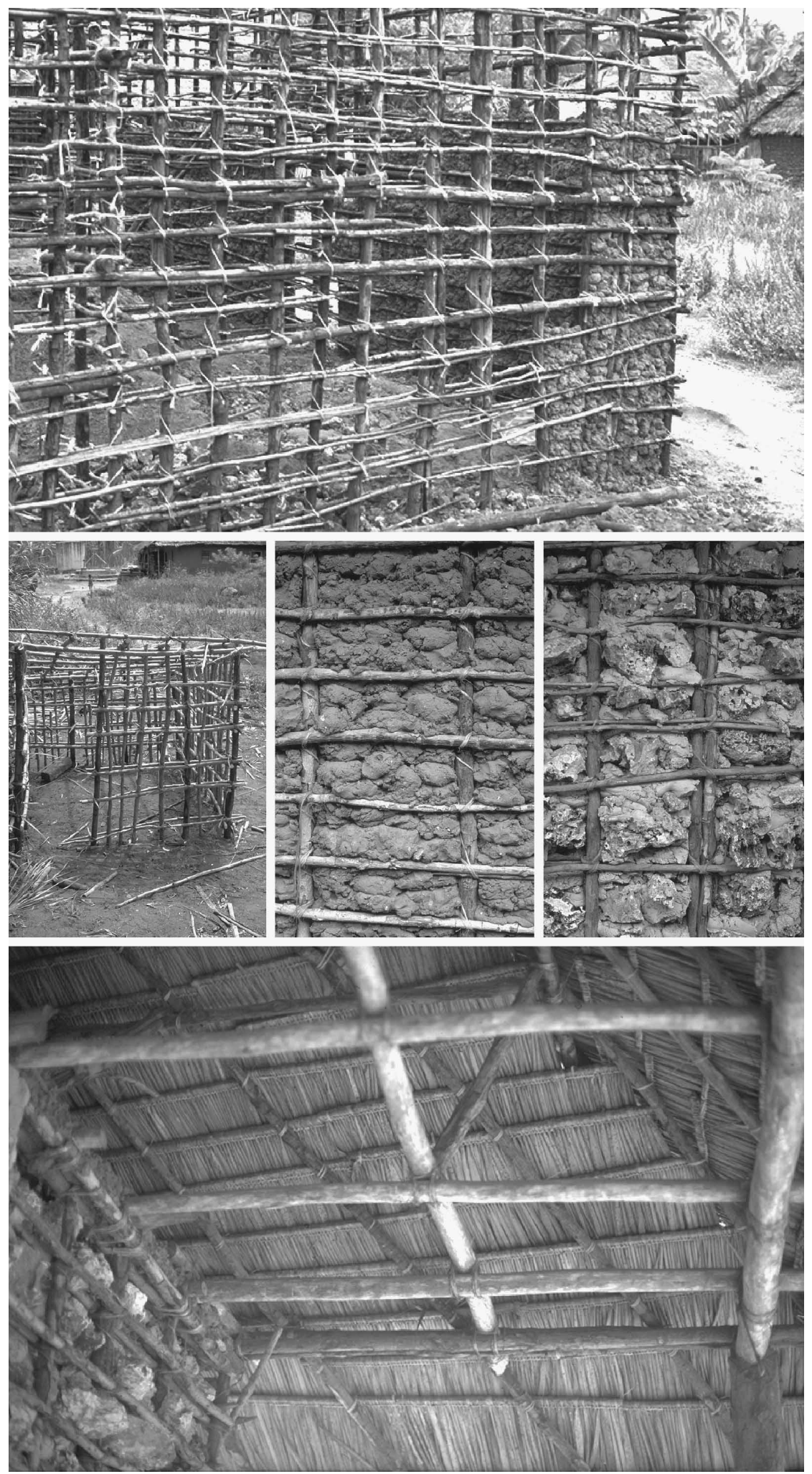
tor. However, it should be highlighted that some houses built with mangrove wood in Lamu (further North) are more than a century old, and some like Fort Jesus (Mombasa) are reported to be several centuries old.

\section{HARVESTING LOCATIONS}

Pole harvesting activities occurred in different sections of the mangrove forest (Fig. 10). However, the actual harvesting locations were often a result of preferred species and pole size availability (cf. Fig. 4) rather than merely an element of accessibility to that section of the forest. Some parts of the creek reportedly had no mangroves that could be harvested, e.g., the Mida/ Majaoni region (Fig. 1). As a result the villagers in this part of the creek indicated they traveled to the Kadaina and Uyombo area to harvest poles of suitable sizes. The closest forest region to Mida/Majaoni is the adjoining Sudi Island, which is left for tourism-related activity like picnicking. Access is restricted and harvesting forbidden by the Kenya Wildlife Service (KWS). In other areas, especially the island regions of Kadaina, Kirepwe, and Kisiwani, the poles were harvested in the forest regions closest to the homesteads (often just outside of the compounds). Harvesting of mangrove trees usually took place whenever poles were required and not on any regular or seasonal basis. The organization of the harvesting activities varied according to different levels of formality. A local formally organized pattern of harvesting involves the interested party approaching a professional mangrove cutter with an authorized license to carry out cutting activities in the forest. Sellers' prices are from $105 \mathrm{KSh}$ per score (1 score $=20$ poles) for pau, to $1000 \mathrm{KSh}$ per score for vigingi (Hirsch and Mauser 1992). A less formally organized harvesting activity comprises of the interested party personally harvesting the mangroves and seeking a permit from the Forestry Department for it. Licenses cost $300 \mathrm{KSh}$ plus $3000 \mathrm{KSh}$ per annum per licensee, however only $50 \%$ of the applicants actually ob- tain a license (Hirsch and Mauser 1992). The Forestry Department often stipulates the exact quantities of poles per any particular utilization class (Table 2). Officially, on average six scores per month are allowed to be cut, but actually eight times that amount is being extracted (Hirsch and Mauser 1992). The informally organized harvesting activity often took a longer time because the parties were not professionals, lacking skill, experience, and efficient equipment. Due to major difficulties in obtaining licenses most people relied on ordered consignments or opted to harvest illegally, which is at the owner's risk of getting caught and having the poles confiscated. The reported high prices of poles, from the dealers or directly from the professional cutters, also encouraged illegal harvesting to some degree. Information on the quantity of mangroves harvested was obtained when interviewing a professional mangrove cutter. He estimated that a nine-ton lorry was filled every time he went on an ordered consignment mission. Such an expedition occurred with a frequency of about one per month (three weeks of cutting and one week of rest). Estimating from this information, in a year there would be 13 such expeditions equaling about 117 tons of harvested mangrove poles for one professional mangrove cutter and his team. However, local people working with mangroves cutting teams of about 50 persons in Gazi, further south, reported about 10 filled lorries per week leaving their mangrove area in the 1960s (Abdulrahman Lali, pers. comm. 1999). These differences in figures may reflect the observed differences in disturbance between the Kenyan north and south coast, but must be considered in the context of the extent and status of the forest, the number of licenses in the area, and the size of the mangrove cutting team. In 1997 in Mida Creek there were four harvesting licenses, but local people reported that resource depletion forced the cutters to move to other areas. Another trend is that as demand actually increases as deduced from utilization patterns and population growth, while

Fig. 5. Top: Mangrove wall skelet (vertical boriti with horizontal fito, cf. Table 2) partially filled with mud.

Fig. 6. Center left: Small cooking shed made of Ceriops tagal.

Fig. 7. Center: Close-up of a mangrove wall filled with mud and clay and,

Fig. 8. Center right, a wall filled with dead coral and cement.

Fig. 9. Bottom: Roof with nguzo and boriti and covered with makuti. 


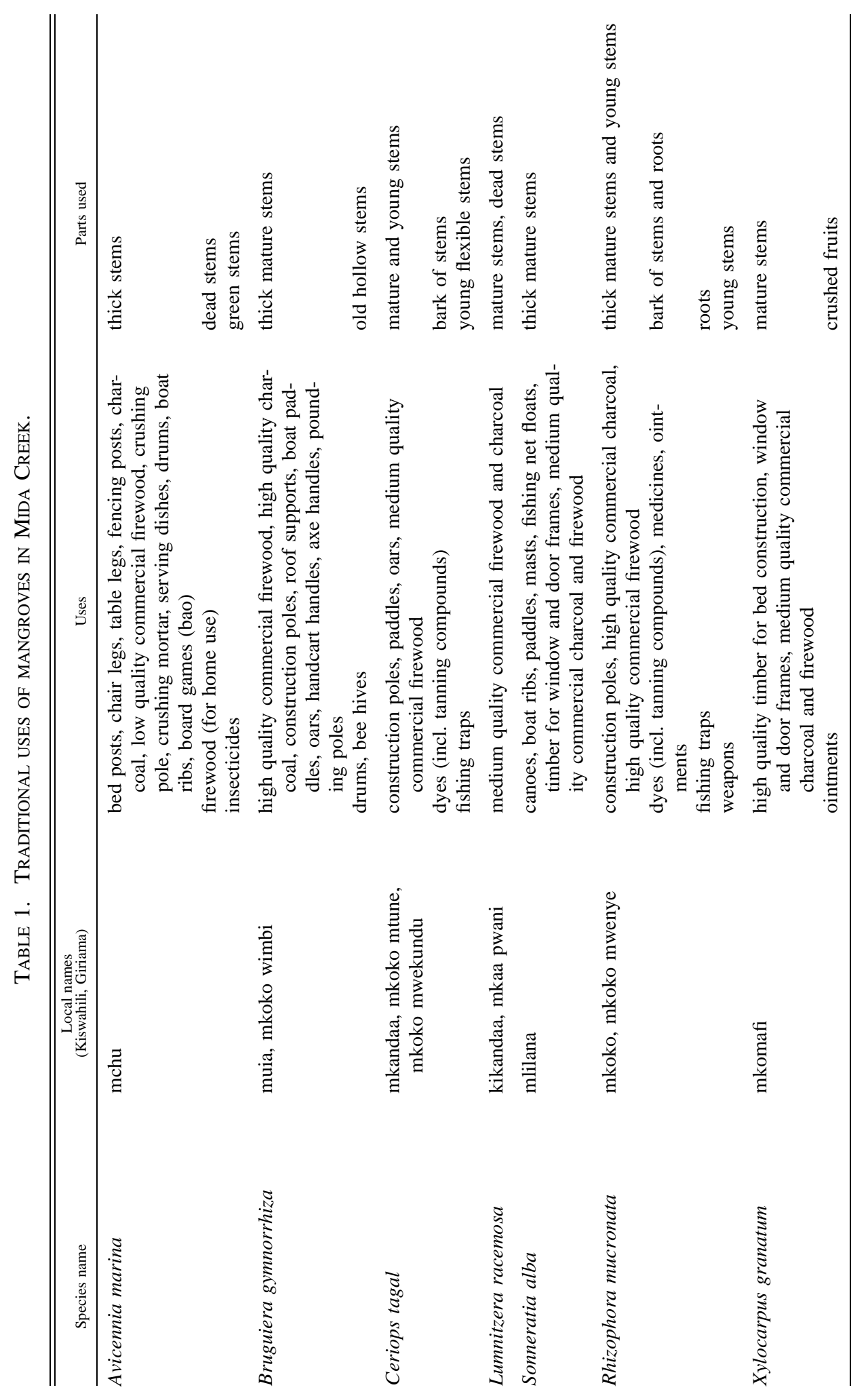


TABle 2. Classification CATEgORIES OF DiFFERENT UTILIZATION ClASSES OF MANGROVE POLES (RoBERTS AND RUARA 1967), QUALIFIED WITH RESPECT TO THE USE AND FOR A SINGLE HOUSE QUANTIFIED PER CATEGORY ACCORDING TO OUR DATA. THE UTILIZATION CLASSES ARE IDENTIFIED BY KISWAHILI WORDS USED LOCALLY (THERE IS NO TRANSLATION FOR THESE TERMS).

\begin{tabular}{lcccl}
\hline \hline $\begin{array}{c}\text { Utilization } \\
\text { class }\end{array}$ & $\begin{array}{c}\text { Diameter range } \\
(\mathrm{cm})\end{array}$ & $\begin{array}{c}\text { Height } \\
(\mathrm{m})\end{array}$ & $\begin{array}{c}\text { Number } \\
\text { required* }\end{array}$ & \multicolumn{1}{c}{ Use } \\
\hline Fito & $2.5-3.5$ & $>4$ & 1000 & wall filling \\
Pau-Mazio & $4.0-11.5$ & $>4$ & 92 & roof filling \\
Boriti & $11.5-13.5$ & $>4$ & 32 & wall supports \\
Nguzo & $14.0-20.0$ & $>4$ & 112 & ceiling and roof supports \\
Vigingi & $20.5-35.0$ & $<4$ & 4 & supports and fencing \\
\hline
\end{tabular}

$* 20$ poles $=1$ score.

supply diminishes as indicated by the reported forest decline, combined with restriction of harvesting as a result of the ban, the locals may turn to other wood materials and to poaching. The degree to which this is admitted cannot reliably be estimated from inquiries.

\section{Mangrove Decline in Mida CReEK}

The majority of people state that the mangrove vegetation is declining (Fig. 11) and further analysis confirms that this is mainly the opinion of those with the highest mangrove knowledge (89\% respondents with expert or good working knowledge). Statistical analysis $\left(\chi^{2}\right.$-test) confronting this group of respondents versus the people with a rough or no idea on mangroves (Fig. 2, Fig. 11) in their reply on the decline of mangroves (fast or notable change against no change or no answer) corroborated this $\left(\chi^{2}=10.792\right.$; d.f. $\left.=1 ; P<0.01\right)$. The main cause given for the observed change is a decline in desired sizes or in overall number of trees.

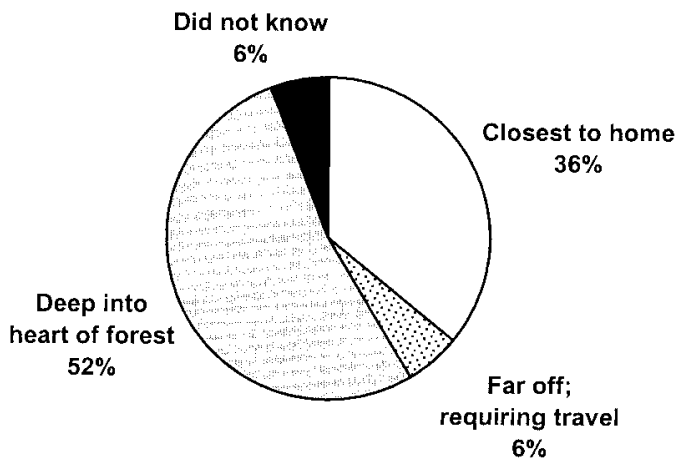

Fig. 10. Location of harvesting activity $(n=100$ respondents).
Kairo and Gwada (1998) and Kairo et al. (n.d. a) observed a clear physiognomic difference of mangrove trees between the forest areas of Uyombo (Fig. 1, left) and Kirepwe (Fig. 1, right). The Uyombo region has been subjected to over-exploitation and as a consequence displays a large proportion of crooked trees (quality class 3), in contrast to Kirepwe (Kairo and Gwada 1998; Kairo et al., n.d. a).

Another indirect cause for decline is the increasingly complex procedures to obtain permits. The latter has been put into a framework of harvesting activities and cause of the observed changes (Fig. 12). Although a ban has been put on mangrove export the system would benefit only for a short term, since the local mar-

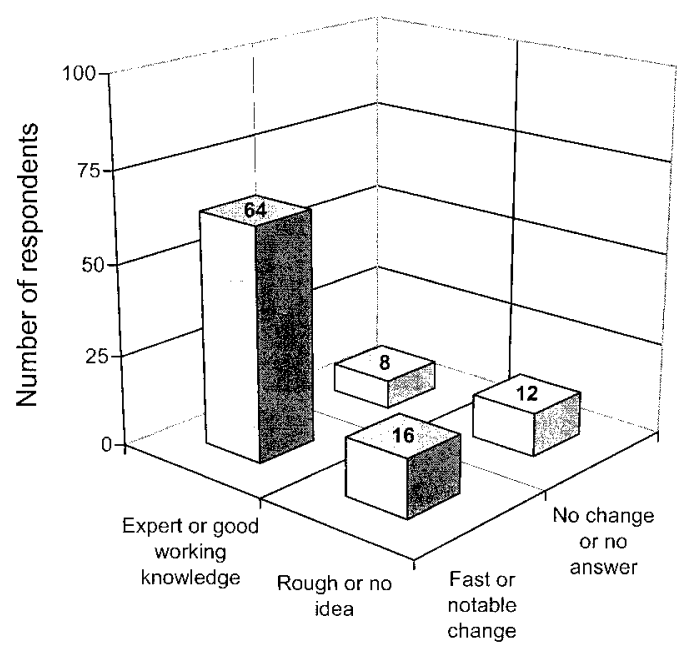

Fig. 11. Respondents' opinions on current forest status classified according to mangrove knowledge (n $=100$ respondents). 


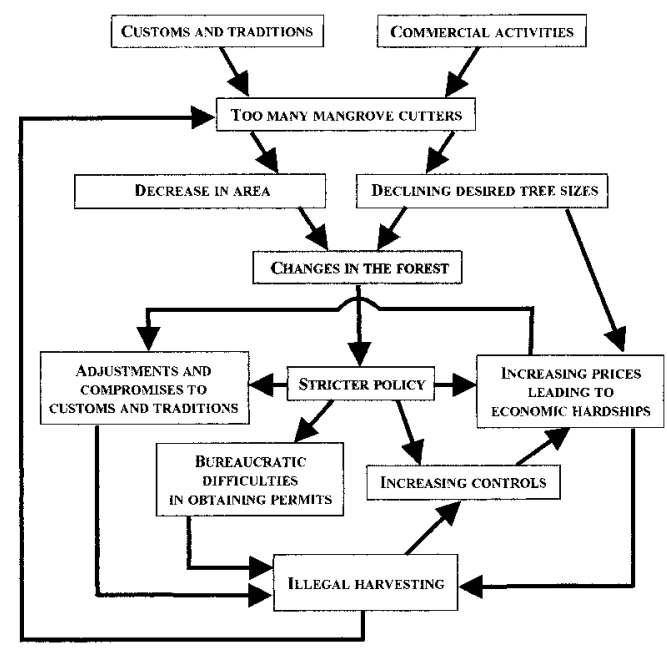

Fig. 12. General framework of harvesting activities and policy leading to the observed changes in Mida Creek. Note the loops forming a vicious circle.

ket also has high demands. The most important task for the Forestry Department would be to carry out a complete inventory of the mangrove resource in the whole country. The inventory should provide forest cover maps as well as data on the forest stocking rates for the main species. Such work is currently being done for Kiunga Marine National Reserve (Kairo et al., n.d. b; Kairo and Kivyatu 2000) and Ramisi (Kairo and Gwada, in prep.). The major obstacle that has prevented rational use and conservation of mangroves in Kenya has been a management policy that consists of controls and prohibitions in the absence of the means to implement them (Ferguson 1993; Kairo 1996).

\section{Conservation And Management Issues}

The wealth of the mangal was well appreciated by the local residents of Mida Creek and reflected in the realization for the need to conserve the forest area. There were various efforts to conserve and replant certain areas by organized groups of people, e.g., Dongokundu Mangrove Planters Association and Viriko/Vimoyoni Women's group. Some even expressed the wish to have stricter and a more rigid control of activities within the forest by the authorities concerned in order to give the forest time to recover. However, policies such as bans on all harvesting activities cannot be applied effectively without examining the consequences for local subsistence communities.

Numerous recommendations have been put forward concerning the direction and steps to be taken towards a mangrove management plan and a sound forestry management scheme to enable sustainable exploitation of the mangrove resources (Kenya Forestry Master Plan 1994). However, few of these, if any, have been implemented to date. A clear understanding of the nature and dynamics of local mangrove ecosystems will be the best guide to any restoration program (Field 1996), and thus necessitates fundamental as well as applied research to fully appreciate and understand and even manage this ecosystem and its utilization patterns. The approach to involve the local population by educating them on the value of the ecosystem to enable them to fully appreciate it, such as in Gazi Bay, Kenya (Kairo 1995) or in the Chilaw Lagoon-Mundel Lake-Puttalam area, Sri Lanka (SFFL 1997; Foell et al. 1999), is presently set up in Mida Creek through the Viriko/Vimoyoni Women's group. This form of environmental education introduces a sense of responsibility among residents on their activities within the forest, but an effective institutionalization of community-based natural resource management and conservation is essential (Agrawal and Gibson 1999). Special training for personnel of the Forestry Department and other authorities managing the mangrove forest area would also result in more appreciation of the value of the resource and hopefully change behavior and attitudes towards exploitation habits and patterns. Duraiappah (1998) also emphasizes that groups that adopt unsustainable activities must be given the incentives (compensation, rewards, taxes, and information provision) to stop. Omodei Zorini and Contini (2000) and Omodei Zorini et al. (2000) have reported that if the local people would be given cattle for instance, they would stop cutting mangrove wood for commercial purposes. Forestry management programs, if put in place in Mida Creek, could result in success particularly now that the population is aware of the need to conserve mangroves. In southern Chile, self-determination and territorial rights are also important factors in the indigenous interests in and commitment to conservation of certain plant species (Aagesen 1998). However, in some cases, the conditions which are deemed to be necessary for the sustainable management 
of a resource appear to be undermined by increasing inequality and conflict (Adger et al. 1997), the latter as the result of the effects of the economic liberalization process in former centrally planned economies (Adger 1999).

Clough (1993) cites that economic indicators do not necessarily provide an adequate description of the contribution of mangrove ecosystems to the daily life and culture of people who have traditionally used mangrove areas. In our view local utilization patterns rather than global usefulness and utilization inventories are required to establish a conservation policy of both mangroves and users' subsistence requirements.

\section{Conclusion}

The local residents of Mida Creek are dependent to a large degree on the mangrove resource, if the lack of economically acceptable alternatives for mangrove resource utilization is considered to cause dependence. The present study provides details on mangrove use that were never reported, such as the preference of wood types for different purposes within a certain use (construction). This shows that local rather than global utilization patterns constitute important sources of information. The majority of Mida Creek's people realize their mangrove forest is degrading and while some are turning to illegal practices (e.g., poaching) because of the bureaucratic difficulties in obtaining a cutting license, others wish to have stricter monitoring and enforcement of the existing mangrove forest policy. The present will and engagement of the local people to protect the mangrove should be an incentive for the government to put a Kenya Forestry Master Plan into action.

\section{ACKNOWLedgments}

We are very grateful to B. Simpson and her entire staff that proved very encouraging and supportive during the fieldwork. Many thanks are due to the practical help of Vladica Sivcev in shaping the questionnaires, and to our local guide on the field. We also thank Willem Brakel, as well as two anonymous reviewers for their comments on the manuscript, and Adriana Sanchéz-Suaréz and Dr. Manzour Hazbon for the Spanish abstract. Research financed by the Fund for Collective Fundamental Research (FKFO) the Belgian National Science Foundation, the Vrije Universiteit Brussel and with a specialization fellowship of the Flemish Institute for the advancement of scientific-technological research in the industry (IWT). This work was presented on the Symposium on Recent Advances and Future Trends in Mangrove Research: Biodiversity, Genetics, Evolutionary Biology and Restoration (July 8-10, 1998, Toulouse, France).

\section{Literature Cited}

Aagesen, D. L. 1998. Indigenous resource rights and conservation of the monkey-puzzle tree (Araucaria araucana, Araucariaceae): a case study from southern Chile. Economic Botany 52(2):146-160.

Adger, W. N. 1999. Exploring income inequality in rural coastal Viet Nam. Journal of Development Studies 35(5):96-119.

, M. Kelly, N. H. Ninh, and N. C. Thanh. 1997. Property rights and the social incidence of mangrove conversion in Vietnam. CSERGE Working Paper GEC 97-21. Centre for Social and Economic Research on the Global Environment, School of Environmental Sciences, University of East Anglia, Norwich, U.K.

Agrawal, A., and C. C. Gibson. 1999. Enchantment and disenchantment: the role of community in natural resource conservation. World Development 27(4):629-649.

Aksornkoae, S., N. Paphavasit, and G. Wattayakorn. 1993. Mangroves of Thailand: present status of conservation, use and management. Pages 83132 in The economic and environment value of mangrove forests and their present state of conservation. International Tropical Timber Organisation/ Japan International Association for Mangroves/International Society for Mangrove Ecosystems, Japan.

Bailey, K. D. 1987. Methods of social research. Collier Macmillon, London, U.K.

Brakel, W. H. 1979. Marine parks and recreation. Pages 409-433 in World Bank Tourism Pricing Policy Study for the Kenya Ministry of Tourism and Wildlife.

Clough, B. F. 1993. The status and value of mangrove forests in Indonesia, Malaysia and Thailand: summary. Pages 1-10 in The economic and environment value of mangrove forests and their present state of conservation. International Tropical Timber Organisation/Japan International Association for Mangroves/International Society for Mangrove Ecosystems, Japan.

Dahdouh-Guebas, F., M. Verneirt, S. Cannicci, J. G. Kairo, and N. Koedam. An exploratory study on grapsid crab zonation in zoned mangrove forests in Kenya. (submitted).

Doute, R., N. Ochanda, and H. Epp. 1981. A forestry inventory of Kenya using remote sensing techniques. Kenya Rangeland Ecological Monitoring Unit report, Nairobi, Kenya.

Durraiappah, A. K. 1998. Poverty and environmental degradation: a review and analysis of the nexus. World Development 26(12):2169-2179.

Farnsworth, E. J., and A. M. Ellison. 1997. The global conservation status of mangroves. Ambio 26(6):328-334.

Ferguson, W. 1993. A land(scape) ecological survey of the mangrove resource of Kenya (Draft Report). Technical Coperation Project (FAO TCP/KEN/ OO51) for the Forestry Department, Ministry of 
Environment and Natural Resources, Nairobi, Kenya.

Foell, J., E. Harrison, and R. L. Stirrat. 1999. Participatory approaches to natural resource management-the case of coastal zone management in the Puttalam District. Summary findings of DFIDfunded research 'participatory mechanisms for sustainable development of coastal ecosystems' (Project R6977), School of African and Asian studies, University of Sussex, Falmer, Brighton, U.K.

Gang, P. O., and J. L. Agatsiva. 1992. The current status of mangroves along the Kenyan coast: a case study of Mida Creek mangroves based on remote sensing. Hydrobiologia 247:29-36.

Hirsch, D. and A. Mauser. 1992. The economic values of mangroves. Two case studies: Mida Creek and Funzi Bay. (Thesis). University of Amsterdam, Netherlands.

Kairo, J. G. 1995. Community participatory forestry for rehabilitation of deforested mangrove areas of Gazi Bay (Kenya). A first approach. Final technical report. University of Nairobi, Department of Botany, Nairobi, Kenya.

1996. Towards alternative views of mangrove forestry in Kenya. In Supporting capacity building in forestry research in Africa. A. Ngeny-Mengech (ed.), International Foundation for Science (IFS), Nairobi, Kenya.

, and P. O. Gwada. 1998. Mangrove of Mida Creek. Ecological survey of Mida Creek. Final technical report. Kenya Wildlife Services, Mombasa, Kenya.

— Structural inventory. Kenya Wildlife Services, Mombasa, Kenya. (in preparation).

, and B. Kiryatu. 2000. Mangrove management survey with and adjacent to Kiunga Marine National Reserve. WWF project KE0087.01, Technical Report. WWF EARO, Nairobi, Kenya/ UNESCO, Nairobi, Kenya.

, F. Dahdouh-Guebas, N. Koedam, D. Van Speybroeck, and C. Ochieng. n.d. a. Natural regeneration status of mangrove forests in Mida Creek, Kenya.

Kairo, J. G., and B. Kivyato. 2000. Management survey within and adjacent to Kiunga Marine National Reserve. WWF Project KE0087.01, Technical Report. WWF EARO, Nairobi, Kenya/UNESCO, Nairobi, Kenya.

B. Kivyatu, J. Church, F. Dahdouh-Guebas, N. Koedam, and R. Höft. n.d. b. Management survey of mangrove forests within the marine protected area of Kiunga, Kenya (presented at the 15th Biennial International Conference of the Estuarine Research Federation "Where the River Meets the Sea," 25-30 Sept. 1999, New Orleans, U.S.A.).

Kennedy, A. 1988. Mida Creek-a study of human impact. (Thesis) University of Edinburgh, Scotland, U.K.

Kenya Forestry Master Plan. 1994. Development Programmes. Ministry of Environment and Natural Resources, Nairobi, Kenya.

KIFCON. 1995. Arabuko Sokoke Forest and Mida Creek. The offical guide. Kenya Indigenous Forest Conservation Programme. Kenya Wildlife Service/ Forestry Department, Nairobi, Kenya.

Kokwaro, J. O. 1985. The distribution and economic importance of the mangrove forests of Kenya. Journal of the East Africa Natural History Society and National Museum 75(188):1-10.

Omodei Zorini, L., and C. Contini. 2000. A multicriterion analysis for the sustainable use of natural resources in Mangrove ecosystems with the involvement of local community. Proceedings of the 4th European Symposium on European Farming and Rural Systems Research and Extension into the Next Millenium, April 3-7, Volos, Greece.

Omodei Zorini, L., C. Contini, F. Barbosa, N. S. Jiddawi, J. Ochiewo, R. Polidori, and J. P. Shunula. 2000. A participatory analysis for a sustainable mangrove management. Presentation at the Meeting on Mangrove Macrobenthos, 7-11, Sept., Mombasa, Kenya.

Rawlins, S. P. 1957. The East-African mangrove trade. Unpublished manuscript \#51 of the National Museum of Kenya, Nairobi, Kenya.

Reddy, S. R. C., and S. P. Chakravarty. 1999. Forest dependence and income distribution in a subsistence economy: evidence from India. World Development 27(7):1141-1149.

Roberts, R. W., and W. W. Ruara. 1967. Lamu Mangrove Inventory. Forest Department, Nairobi, Kenya.

Salim, A. I. 1985. Kenya's people. People of the coast: Swahili. Evans Brothers Limited, Nairobi, Kenya.

SFFL. 1997. Performance report for the years 1994, 1995 and 1996. Small Fishers Federation of Lanka, Pambala, Kakkapalliya, Sri Lanka.

Spalding, M., F. Blasco, and C. Field. 1997. World mangrove atlas. The International Society for Mangrove Ecosystems, Okinawa, Japan.

Tomlinson, P. B. 1986. The botany of mangroves. Cambridge University Press, Cambridge, UK.

\section{APPENDIX 1 \\ Questionnaire Used During the Field SURVEY}

1. What do you understand by the term mangrove?

2. What are the uses of mangrove within your household?

a) Fuel-wood (firewood and charcoal)

b) Timber (house and boat construction)

c) Medicinal products (medicine and ointments) 
d) Furniture (chairs, tables, shelves, utensils, boat masts, paddles, fishing equipment)

e) Food (for man and animal feeds)

f) Others (specify)

3. Which of the above listed uses is the most used within your household?

4. Do you have a preferred species of mangrove for use as poles for house construction? If so, which one (vernacular names)?

5. How long do the houses last once constructed with mangrove poles, before they require replacing?

6. Where, within the forest, does the harvesting activity take place?

a) Along the forest edge, closest to home

b) Deep in the heart of the forest

c) In a forest region that is far off and requires traveling

d) Do not know
7. How do you organize your harvesting?

8. How frequently do you visit the forest to harvest mangroves?

a) At least once a month

b) Once a month

c) Twice a month

d) Once in two months

e) Whenever necessary (specify)

9. What is the size of your household?

10. Do you harvest mangroves for uses other than those within your household? If so, for what purposes?

a) Small trading

b) To stock in a commercial place

c) Other uses (specify)

11. Do you buy mangrove poles? If yes, from whom?

12. Has it become easier or more difficult to harvest mangroves? Why do you think so? Has the forest changed? 